\title{
An Examination of the Perceived Impact of Medicaid Expansion on United States of America's Economy
}

\author{
Babatunde Ademola Akinbobola \\ Department of Public Policy \\ Nelson Mandela College of Government and Social Sciences \\ Southern University and A\&M College \\ Baton Rouge, Louisiana, USA 70807
}

\begin{abstract}
Health disparities is a major concern to policymakers across the 50 states of USA. At the same time access to affordable healthcare is a major challenge and very political in the country. Despite the health disparity challenge little is known about how lack of access to affordable care has contributed to health disparity. As a result, this particular study has utilized descriptive study, available data, and literature to address the little gap. The analysis of this study has shown that Medicaid together with the ACA have played a major role in the reduction of the number of people without health insurance coverage in the United States. Therefore, further expansion of the ACA and the Medicaid insurance program will go a long way to expand the impact of the ACA in addressing the obvious health disparity that the country is battling with in the midst of this Covid-19 pandemic. It has also been observed in the literature that the passage of the ACA broke the political deadlock that long thwarted the national progress toward equitable, quality, universal, affordable health care. Again, it was further observed that the ACA and the expansion of Medicaid are perceived to extend coverage for the uninsured individuals who are unduly under the low-income category and people of color, edges health insurance mishandlings, and ensures improvements in the quality of care. Given the above narratives and significance of the expansion of the ACA and Medicaid health insurance policy, it is more prudent for all the 50-states across the United States of America to adopt and expand ACA and Medicaid policy in order to reduce health disparity and also ensures economic growth and development. Keywords: Medicaid, Health-Disparity, Development, Growth, ACA, Policy, Economy
\end{abstract}

DOI: $10.7176 /$ PPAR/11-1-04

Publication date: January $31^{\text {st }} 2021$

\section{INTRODUCTION}

Health insurance coverage is one of the significant element citizens of many countries across the globe get from their political leaders. Very importantly, many societies and nations across the globe including United States of America are striving very hard to achieve a universal health insurance coverage. A typical case in point is the need to expand Medicaid healthcare policy in United States of America and the introduction of the affordable healthcare. This is because according to a renown healthcare policy scholar Adu-Frimpong, a healthy population is a wealthy nation, therefore many societies and economies are trying very hard to give their citizens either social healthcare insurance policy or mandatory health insurance policy to achieve a healthy nation. Over the years Medicaid health insurance coverage has been very limited to very few privilege Americans leaving many of the vulnerable citizens expose to many health-related issues due to lack-of-coverage and fear of accessing healthcare facility due to huge medical bills. According to the Kaiser Family Foundation (2013), a non-profit health advocacy, "Health insurance can be expensive, and is therefore often out of reach for lower and moderate-income families. Therefore, in order to make coverage obtainable for families that otherwise could not afford it and to encourage broad participation in health insurance, the Affordable Care Act (ACA) includes provisions to lower premiums and out-of-pocket costs for people with low and modest incomes" (Kaiser Family Foundation, 2020). The ACA provides financial assistance to reduce monthly premiums and out-of-pocket costs in an effort to expand access to affordable health insurance for people with moderate and low-income - particularly those without access to affordable coverage through their employer, Medicaid, or Medicare (Kaiser Family Foundation, 2020). In fact, getting access to social health insurance policy/coverage gives the individual citizens peace of mind.

Aside the peace of mind that comes with having health insurance coverage, there are enormous health wellness benefits as well, especially on children. According to Cohodes et al. (2016), children with health insurance coverage are better prepared to learn in school, complete high school, and succeed in life, all other things being equal. Additionally, Furman \& Fielder (2016) also argued that children health insurance coverage and its expansions in the ACA suggest that children who gained health care access achieved improvements in health, education, labor market outcomes. It was further observed in the literature that pre-teen and early-teen children who had Medicaid coverage resulted in better health including lower mortality in their late-teen years (Sommers, Baicker, \& Epstein, 2012), as well as lower hospitalization rates in adulthood (Wherry, Miller, Kaestner, \& Meyer, 2015). It is also observed in the literature that Connecticut's health insurance carriers play a major role in the state's economy, responsible for tens of thousands of jobs and billions of dollars in economic output according to a new 
study. Meanwhile, the Connecticut Economic Resource Center study found the private sector health insurance industry supported 48,560 jobs and generated $\$ 15.5$ billion in direct and indirect economic activity in 2018 (Connecticut Economic Research Center, 2019).

Stressing on the need and the significance of expanding Medicaid in United States of America, Governor John Edwards of Louisiana state argues that "through Medicaid expansion, we are bringing our federal tax dollars back to Louisiana to save lives and improve health outcomes for the working poor people of our state" (Louisiana Department of Health, Medicaid Expansion Annual Report 2016/17, p.2). Also, in a study conducted by Louisiana State University in 2018, it was argued that, the need to expand Medicaid coverage is very critical because it has "provided for about $97.5 \%$ federal contribution for state fiscal year 2017 , a $94 \%$ federal contribution in calendar year 2018, a 93\% federal contribution in calendar year 2019, and a 90\% federal contribution from calendar year 2020 and beyond, assuming no further changes in Medicaid at the federal level." Additionally, Richardson, Llorens, \& Heidelberg (2018) further explained this particular federal infusion by arguing that the report in turn "creates and sustains economic activity in the healthcare sector which then impacts all other sectors of the state's economy" (p. 2). In the report, it was estimated that Louisiana received an estimated amount of $\$ 1.85$ billion in 2017-State Fiscal Year, approximately \$1.77 billion in 2018-State Fiscal Year, and anticipated \$1.8 billion in 2019-State Fiscal Year in federal dollars to support its Medicaid Expansion program (Richardson, Llorens, \& Heidelberg, 2019 , p. 5). Apart from the fiscal contribution, Medicaid expansion in relation to federal dollars create and also add to employment, earnings, payments and tax receipts into some of the Medicaid-practice-State's economy.

Despite the significant role Medicaid plays in the economy of the United States of America, little efforts have been made to expand this healthcare policy. According to the literature, the ACA is a crisis in U.S. public health policy. Following the full implementation of the ACA, which began on January 1, 2014, when the individual and employer responsibility provisions took effect, state health insurance exchanges started to operate, the Medicaid expansions took effect, and the individual and small-employer group subsidies became effective (Rosenbaum, 2011). In the literature, Abraham (2014) argued that the ACA uses two major approaches to expand health care coverage. Where, he argued that the first mechanism is financial assistance subsidy offered through marketplace insurance exchanges. While the second is through an expansion of Medicaid eligibility, in which states have the option to offer coverage to all individuals with a family income at or below $138 \%$ of the federal poverty level (Abraham, 2014). But many states are reluctant towards the implementation of this particular healthcare policyexpansion of Medicaid.

\section{LITERATURE REVIEW}

The ACA as a perceived policy to expand Medicaid has divided Americans like few other issues in recent memory (Balz, 2010). According to Balz (2010), the battle has been ferocious and the outbreaks voluble including the "spurious claim that the ACA would establish death panels that would have the power to decide whether Grandma and Grandpa lived or died". Meanwhile, Thompson, Gusmano, and Shinohara (2018) argued that "since the passage and implementation of the ACA, instead of cooperative federalism between the federal government and the states, the ACA has faced growing partisan polarization in the area of intergovernmental intransigence, conflict, and even "war" (p.136). Congress especially Republican leaders and Tea Party activists have played a big role in the fight to eliminate the ACA, forcefully expressed in their continued crusade over the past 10 years to "repeal and replace" the ACA (Moore, 1945; Himmelstein \& Woolhandler, 1986). The U. S. Congressional Research Service also underscored that, "Since the ACA's enactment, lawmakers opposed to specific provisions in the ACA or the entire law have repeatedly debated its implementation and considered bills to repeal, defund, delay, or otherwise amend the law (Moore, 1945; Himmelstein \& Woolhandler, 1986).

Sadly enough, their main objection and argument to the law is that the ACA is a modern day "socialized medicine" (Moore, 1945; Himmelstein \& Woolhandler, 1986; Faria, 2018; Sen 2015) that "ration medicine access" (Diener, 1983) and "would make private insurance more expensive, undermine Medicare for seniors, and generally wreck everything that was good about the US health care system" (Cohn, 2020). Also, Congressional Republicans charge that the ACA would impose big financial burdens on states, diminish the quality of care, and limit choices (Jost, 2017; Shaffer, 2013; Willison \& Singer, 2017). The ACA has also faced court challenges. In June 2012, the U.S. Supreme Court ruled that states did not have to expand Medicaid for the poor and disabled (Barnes, 2012).

Perhaps, the most glaring example to undermine the ACA is the rejection of Medicaid expansion by some Republican state officials (e.g. Florida, Georgia, and Texas), consequently "millions of low-income people remain uninsured" (Cohn, 2020). Not the least, even President Trump has professed his intention to undo the ACA (Friedman, Andrews, \& Humphreys, 2017), bordering on "sabotage" (Thompson, 2020), and "no replacement plan" (Obama, 2017) whatsoever upon "repeal-and-replace" of the ACA. More poignantly, "the Trump administration has attacked the objectivity of the nonpartisan Congressional Budget Office (CBO) whose periodic scoring of Republican proposals forecast that it would greatly increase the number of uninsured" (Thompson, Gusmano, \& Shinohara, 2018, p. 400). Specifically, according to the CBO, elimination of the ACA would increase the number of uninsured people by 17 million in 2018, rising to 27 million and 32 million in 2020 and 2026, respectively 
(CBO, 2017).

Surprisingly, It was observe in the literature and several post, including the New York times that, on the first day in office of the $45^{\text {th }}$ President of the United States of America, Trump issued an executive order directing federal agencies to rip to shreds the ACA "to the maximum extent permitted by law" and "minimize the unwarranted economic and regulatory burdens" of the ACA (The White House, 2017; Center on Budget and Policy Priorities, 2017). Readers learned that the executive order included the instructions to agencies to "exercise all authority and discretion available to them to waive, defer, grant exemptions from, or delay the implementation of any provision or requirement of the Act that would impose a fiscal burden on any State or a cost, fee, tax, penalty, or regulatory burden on individuals, families, healthcare providers, health insurers, patients, recipients of healthcare services, purchasers of health insurance, or makers of medical devices, products, or medications" (The White House, January 20, 2017; Center on Budget and Policy Priorities, 2017). In another instance, President Trump said that "politically the best thing to do would be to let the ACA "explode" (Center on Budget and Policy Priorities, 2017). Goldstein and Eilperin (2017) argued and also reported a recent statement from the White House that explained that the Congress needs to repeal and replace the disastrous Obamacare and provide real relief to the American people (Goldstein \& Eilperin, 2017). Very debatably, the Republicans were of the view that the Obamacare has led to higher costs and fewer insurance options for millions of Americans (The White House, 2017). It was further argued by the president Trump in the White House that the 2010 healthcare law has brought the American people rising premiums, unaffordable deductibles, fewer insurance choices, and higher taxes. As a result, president Trump has vowed to repeal and replace the supposed healthcare disaster, and that is exactly what he has spent about 4 years working with Congress to repeal the policy (The White House, 2017).

According to Jost (2017), on March 6, 2017, the House Republican leadership introduced the American Health Care Act (AHCA) to repeal and replace the ACA. Wilensky (2017) also explained that on May 4, 2017 by a vote of 217 to 213, the House of Representatives passed the AHCA, all Democrats and twenty Republicans voted against the bill. In the main, the AHCA proposed to repeal portions of the ACA by eliminating especially ACA's mandate penalties, insurance premium subsidies, and Medicaid expansion eligibility (CBO, 2017). Further, the AHCA converted Medicaid from a fiscal entitlement where the federal government must match whatever a state spends to a "capitated" block grant with an upper limit on the federal subsidy (Thompson, Gusmano, \& Shinohara, 2018, pp. 400-401). The AHCA as proposed would make several unprecedented changes to Medicaid in particular and health care in general (Dobson, Davanzo, \& Haught, 2017; Fiedler, Aaron, Adler, and Ginsburg, 2017). First, it would effectively end ACA's Medicaid expansion provision, which would result to loss of coverage to estimated 32 million people by 2026 (CBO, 2017). Second, it would increase premiums in the non-group market (exchanges) to about $50 \%$ in the first year following the elimination of the Medicaid expansion and the marketplace subsidies, and premiums would double by 2026 (CBO, 2017). Third, the AHCA would change the longstanding arrangement between states and the federal government by placing limits on federal financial support to states (Dobson et al., 2017). The most recent CBO calculation of the House passed version of the AHCA indicates that this would reduce federal Medicaid support to states by a total of $\$ 834$ billion over a 10-year period, 2017-2026, representing a $26 \%$ cut in federal Medicaid payments (CB0, 2017). On the same vein, the $\mathrm{CBO}$ estimate that the repeal of the ACA would trigger a net increase of federal budget deficits by $\$ 109$ billion over the 2013-2022 period (CBO, 2012), while the number of the uninsured will rise to 18 million in the first year of the repeal, then increase to 27 million, and then to 32 million in 2026 (CBO, 2017).

Furthermore, repeal would have wider economic impacts including $\$ 140$ billion loss in federal funding for health care in 2019, resulting to the loss of 2.6 million jobs (mostly in the private sector) across all states (Ku, Steinmetz, Brantley, \& Bruen, 2017). And if replacement plans are not in place, from 2019-2023, there will be a cumulative loss of $\$ 1.5$ trillion in gross state products and a $\$ 2.6$ trillion reduction in business output (Ku et al, 2017).

\section{METHODOLOGY}

This study adopts a descriptive research design to explain the need for Medicaid expansion and its perceived important to the United States of America's economy. A secondary data was retrieved from the Louisiana Department of Health, and over 400 literature searches. In fact the data from the Louisiana Department of Health was used from a compilation of extracts from state and national databases from 2000 to 2018. The compilation of data extracts used in the data collection includes the Louisiana Department of Health Office of Behavioral Health and Office of Public Health Bureau of Infectious Diseases, and Medicaid Expansion and the Louisiana Economy. Additionally, a Boolean search for health disparity, access to health care, social insurance policy, and importance of Medicaid were conducted. This ancestral literature search helps the researcher to retrieved the relevant literature and data for the analysis of the data. Data information including the Boolean search made used of the study by Madeline Guth, Rachel Garfield, Robin Rudowitz (March 2020) on the Effects of Medicaid Expansion under the ACA: Updated Findings from a Literature Review, published by Kaiser Family Foundation. All the data variables were measured on interval-ratio scale. Tables, bar graphs, and pie-charts were used to analyze the study. 


\title{
DATA PRESENTATION AND DISCUSSION
}

\section{FEDERAL PAYMENT TOWARDS MEDICAID ACTIVITY}

\author{
- Inpatient Care \\ - Outpatient Care \\ - Pharmacy \\ - Physicians and other professions \\ Other Medical Services \\ Administration of Program
}

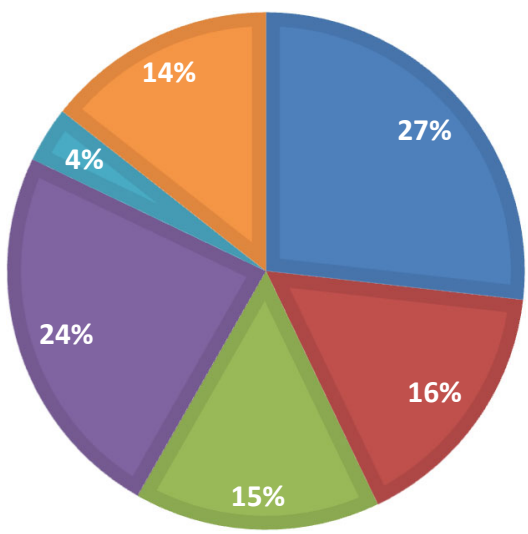

Figure 1: Federal Payment towards Medicaid Activities

Source: Louisiana Health Department, 2018 and James A. Richardson, Jared J. Llorens, \& Roy L. Heidelberg (March 2018). Medicaid Expansion and the Louisiana Economy, p. 4.

In all about $\$ 1,850$ of federal payment are devoted to Medicaid activity. Figure 1 discusses federal payment towards Medicaid operational activities. According to the data, about of $27 \%$ of the total federal payment towards Medicaid functions in the country goes to inpatient care, $16 \%$ goes to outpatient care, $24 \%$ goes to physicians and other professions in the healthcare markets, $15 \%$ goes pharmacy assistance, $14 \%$ goes to administration of programs, and $4 \%$ of the payment goes other medical services.

\section{BUSINESS ACTIVITIES PAYMENT TOWARD MEDICAID Administration of ACTIVITY Program, 476.8,}

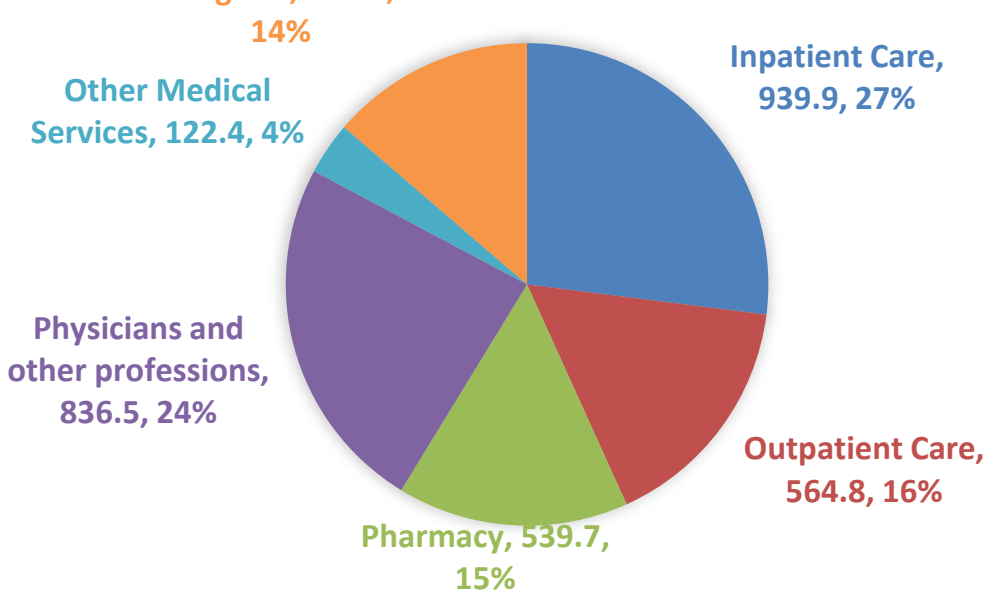

Figure 2: Business Activities Payment Towards Medicaid Activities

Source: Louisiana Health Department, 2018 and James A. Richardson, Jared J. Llorens, \& Roy L. Heidelberg (March 2018). Medicaid Expansion and the Louisiana Economy, p. 4.

In all about $\$ 3,480.1$ of business activities payments are devoted to Medicaid activity. Figure 2 discusses business activities payment towards Medicaid operational activities. According to the data observed in Figure 2, about of $27 \%$ of the total business activities payment towards Medicaid functions in the country goes to inpatient care, $16 \%$ goes to outpatient care, $24 \%$ goes to physicians and other professions in the healthcare markets, $15 \%$ 
goes pharmacy assistance, $14 \%$ goes to administration of programs, and $4 \%$ of the payment goes other medical services.

\section{Personal Earnings Payment Towards Medicaid Activity}

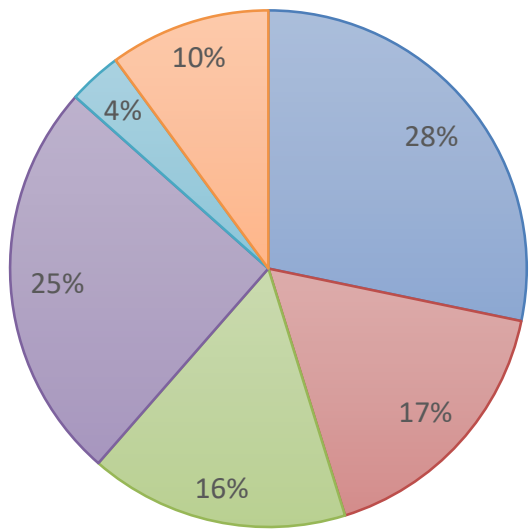

\author{
口Inpatient Care \\ $\square$ Pharmacy \\ $\square$ Other Medical Services
}

口Outpatient Care

$\square$ Physicians and other professions

$\square$ Administration of Program

Figure 3: Personal Earnings Payment towards Medicaid Activities

Source: Louisiana Health Department, 2018 and James A. Richardson, Jared J. Llorens, \& Roy L. Heidelberg (March 2018). Medicaid Expansion and the Louisiana Economy, p. 4.

In all about $\$ 1,118.2$ of personal earnings payment are devoted to Medicaid activity. Figure 3 discusses federal payment towards Medicaid operational activities. According to the data, about $28 \%$ of the total personal earning payment towards Medicaid functions in the country goes to inpatient care, $17 \%$ goes to outpatient care, $25 \%$ goes to physicians and other professions in the healthcare markets, $16 \%$ goes pharmacy assistance, $10 \%$ goes to administration of programs, and $4 \%$ of the payment goes other medical services.

\section{Employment Towards Medicaid Activity}

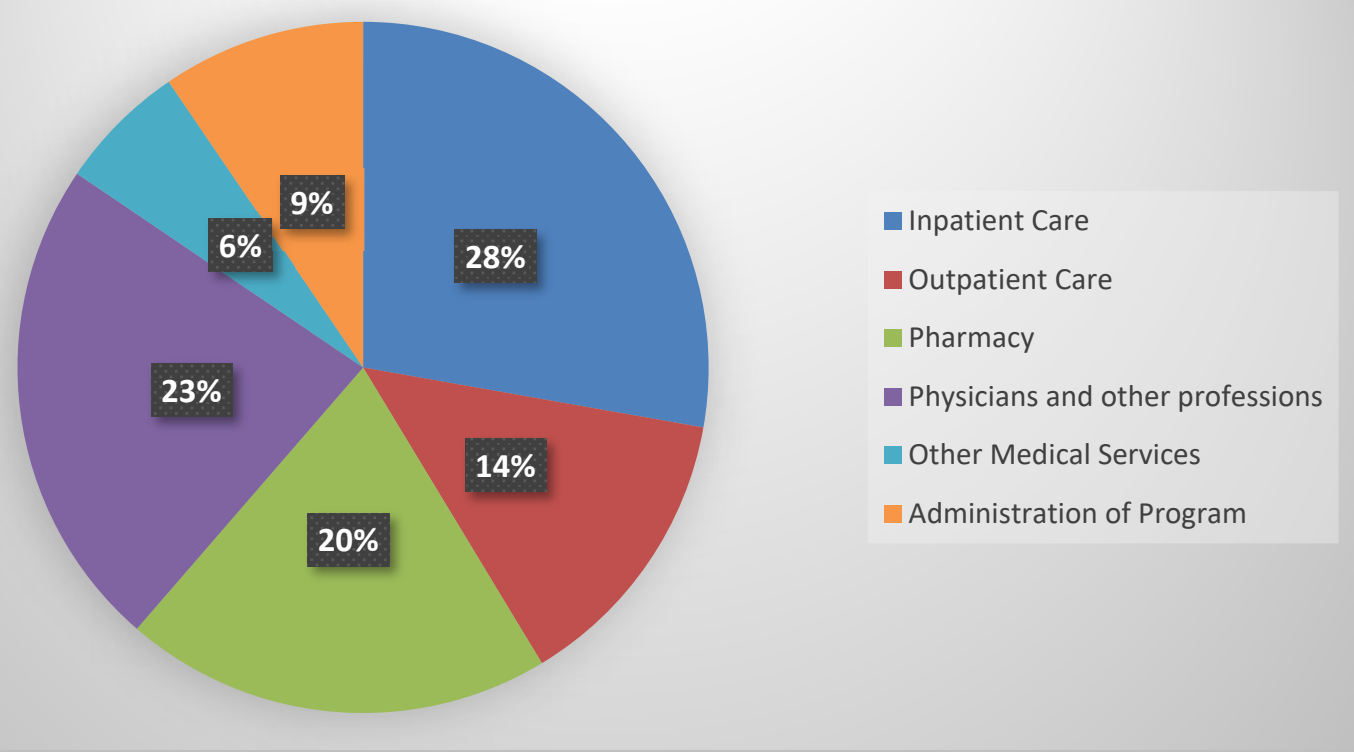

Figure 4: Federal Employment Associated with Medicaid Activities

Source: Louisiana Health Department, 2018 and James A. Richardson, Jared J. Llorens, \& Roy L. Heidelberg (March 2018). Medicaid Expansion and the Louisiana Economy, p. 4.

In all about 19, 195 of federal employment are generated from Medicaid activity. Figure 4 discusses federal employment activities associated with the implementation and operation of the Medicaid operational activities. 
According to the data, about $28 \%$ of the total federal employment activities which are associated with Medicaid functions in the country goes to inpatient care, $14 \%$ goes to outpatient care, $23 \%$ goes to physicians and other professions in the healthcare markets, $20 \%$ goes pharmacy assistance, $9 \%$ goes to administration of programs, and $6 \%$ of the payment goes other medical services.

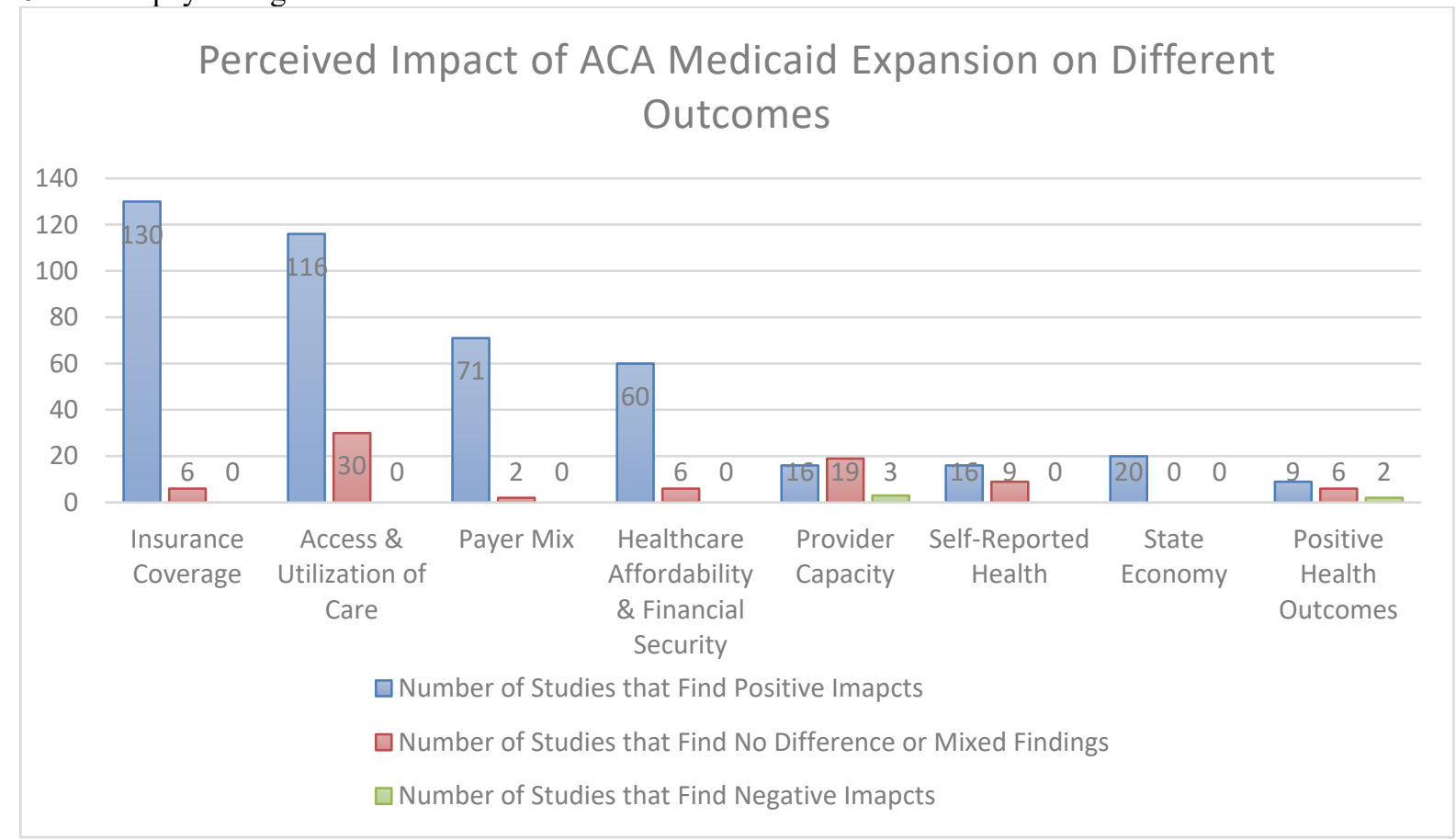

Figure 5: Perceived Impact of ACA Medicaid Expansion on Different Outcomes

Source of Data: Madeline Guth, Rachel Garfield, Robin Rudowitz (March 2020). Effects of Medicaid Expansion under the ACA: Updated Findings from a Literature Review. Kaiser Family Foundation.

Figure 5 discusses the perceived impact of Medicaid/ACA expansion on a national economy. The data used here were obtain from the Kaiser Family Foundation research report. In relation to the recent national report by Kaiser that summarized findings from more than 400 studies on the effect of Medicaid expansions found "general positive effects of the ACA on Medicaid expansion on different outcomes" including "gains in coverage, improvements in access, financial security, and some measures of health status/outcomes, and economic benefits for states and providers" (see Figure 5 for more details).

In relation to Figure 5, a total of 136 articles were reviewed for insurance coverage. Out of the 136, about 130 of the total articles argued that insurance coverage through the expansion of Medicaid or Affordable Care Act (ACA) have positive impact on health outcomes, while the remaining 6 articles revealed a mixed finding towards the health outcomes (or were indifferent in the impacts).

Regarding access and utilization of care, a total of 146 articles were reviewed for analysis. Out of the 146, about 116 of the total articles argued that the attainment of access and utilization of care through the expansion of Medicaid or Affordable Care Act (ACA) among citizens have positive impact on health outcomes, thereby minimizing health disparities, while the remaining 30 articles revealed a mixed finding towards the health outcomes (or were indifferent in the impacts) (see Figure 5 for more details).

With regards to healthcare affordability and financial security, a total of 66 articles were reviewed for analysis. Out of the 66, about 60 of the total articles argued that healthcare affordability and financial security could be achieved through the expansion of Medicaid or Affordable Care Act (ACA) among citizens, which as a result will have positive impact on health outcomes, thereby minimizing health disparities, while the remaining 6 articles revealed a mixed finding towards the health outcomes (or were indifferent in the impacts) (see Figure 5 for more details).

Above all, a total of 17 articles were revealed to analyze the extent to which Medicaid expansion will exert influence on positive health outcome. Out of the 17 articles, 9 of the reviewed articles argued that the expansion of Medicaid is expected to exert a considerable positive on health outcomes, while 6 of the articles had mixed findings or were indifferent between positive and negative, but the remaining 2 articles underscored in their findings that depending on the nature of the implementation of the expansion of the Medicaid program or policy could end up having a negative impact on health outcomes (see Figure 5 for more details). 


\section{CONCLUSION}

There is an undeniable fact that expanding the Medicaid coverage will contribute to access to insurance coverage for the most vulnerable and people with underlying conditions; improve access and utilization of care; appreciate the payer mix strategy; ensures healthcare affordability and financial security and also contribute positively to economies of the various states, and above ensures positive health outcomes as a way to minimize health disparities and inequity. The analysis of this particular paper has shown that Medicaid together with the ACA have played a major role in the reduction of the number of people without health insurance coverage in the United States. Therefore, further expansion of the ACA and the Medicaid insurance program will go a long way to expand the impact of the ACA in addressing the obvious health disparity that the country is battling with in the midst of this Covid-19 pandemic. This is because if I recall from the writings of Cohen (2020), it is argued that the passage of the ACA broke the political deadlock that long stymied national progress toward equitable, quality, universal, affordable health care. Meanwhile, as rightfully observed by Shaffer (2013) the ACA and the expansion of Medicaid are perceived to extend coverage for the uninsured individuals who are unduly under the low-income category and people of color, edges health insurance mishandlings, and ensures improvements in the quality of care. Given the above narratives and significance of the expansion of the ACA and Medicaid health insurance policy, it is more prudent for all the 50-states across United States of America to adopt and expand ACA and Medicaid policy in order to reduce health disparity and also ensures growth and development.

\section{REFERENCES}

Adu-Frimpong, A. (2016). Theory and Practice of Health Economics. IISTE.org.

Abraham, J.M. (2014). How Might the Affordable Care Act's Coverage Expansion Provisions Influence Demand for Medical Care? The Milbank Quarterly, 92(1), pp. 63-87.

Anderson, G. F., Willink, A., \& Osborn, R. (2013). Reevaluating "Made in America" - Two Cost-Containment Ideas from Abroad. New England Journal of Medicine, 368, 2247-2249.

Adkinson, J. M., \& Chung, K. C. (2014, August). The Patient Protection and Affordable Care Act: A Primer for Hand Surgeons. Hand Clinics, 30(3), 345-vii.

Antos, J. R., \& Capretta, J. C. (2020, April 10). The ACA: Trillions? Yes. A Revolution? No. Health Affairs. https://www.healthaffairs.org/do/10.1377/hblog20200406.93812/full/

Askin, E., \& Moore, N. (2012). The Health Care Handbook. Washington University in St. Louis.

Auerbach, D. I., \& Kellermann, A. L. (2011). How Does Growth in Health Care Costs Affect the American Family? RAND Corporation. Research Brief.https://www.rand.org/pubs/research_briefs/RB9605.html.

Avery, K., Finegold, K., \& Whitman, A. (2016). Affordable Care Act Has Led to Historic, Widespread Increase in Health Insurance Coverage. U.S. Department of Health and Human Services. Office of the Assistant Secretary for Planning and Evaluation. https://aspe.hhs.gov/system/files/pdf/207946/ACAHistoricIncreaseCoverage.pdf.

Ballard, M. (2016, January 14). Gov. John Bel Edwards Issues Executive Order to Expand Medicaid. The Advocate. http://www.theadvocate.com/baton rouge/news/politics/article a035f7fd-fa48-5df6-9333b3flceaa184d.html.

Balz, D. (2010). Landmark - America's New Health Care Law and What It Means for Us All. Introduction. The Washington Post. New York: Thorndike Press.

Birkland, T. A. (2015). An Introduction to the Policy Process. New York: Routledge.

Blumenthal, D., Abrams, M. K. (2020, February 26). The Affordable Care Act at 10 Years: What's Changed in Health Care Delivery and Payment? Commonwealth Fund. https://www.commonwealthfund.org/publications/journal-article/2020/feb/aca-at-10-years-changed-healthcare-delivery-payment.

Brown, D. W., Kowalski, A. E., \& Lurie, I. Z. (January 2015). Medicaid as an Investment in Children: What is the Long-Term Impact on Tax Receipts?” National Bureau of Economic Research (NBER), Working Paper No. 20835.

Brownson, R.C., Seiler, R., \& Eyler, A. A. (2010). Measuring the Impact of Public Health Policy. Centers for Disease Control and Prevention. https://www.cdc.gov/pcd/issues/2010/jul/09_0249.htm.

Centers for Disease Control and Prevention. (2013). Ten Great Public Health Achievements in the $20^{\text {th }}$ Century. https://www.cdc.gov/about/history/tengpha.htm.

Center on Budget and Policy Priorities (2017). Sabotage Watch: Tracking Efforts to Undermine the ACA. https://www.cbpp.org/sabotage-watch-tracking-efforts-to-undermine-the-aca.

Chernew, M. E., Hirth, R. A., \& Cutler, D. M. (2003). Increased Spending On Health Care: How Much Can The $\begin{array}{lllll}\text { United } & \text { States } & \text { Afford? } & \text { Health }\end{array}$ https://www.healthaffairs.org/doi/pdf/10.1377/hlthaff.22.4.15.

Claxton, G. et al. (2016, December 12). Pre-existing Conditions and Medical Underwriting in the Individual Insurance Market Prior to the ACA. Kaiser Family Foundation. https://www.kff.org/health-reform/issue- 
brief/pre-existing-conditions-and-medical-underwriting-in-the-individual-insurance-market-prior-to-theaca/.

Claxton, G. et al. (2019, October 4). Pre-Existing Condition Prevalence for Individuals and Families. Kaiser Family Foundation.https://www.kff.org/health-reform/issue-brief/pre-existing-condition-prevalence-forindividuals-and-families/.

Cohen, R. A. et al. (2020). Health Insurance Coverage: Early Release of Estimates From the National Health Interview Survey, 2019. U.S. Department of Health and Human Services. Centers for Disease Control and Prevention. National Center for Health https://www.cdc.gov/nchs/data/nhis/earlyrelease/insur202009-508.pdf.

Cohen, R. A., Martinez, M. E., \& Zammitti, E. P. (September 7, 2016). Health Insurance Coverage: Early Release of Estimates from the National Health Survey, January-March 2016. National Center for Health Statistics. https://www.cdc.gov/nchs/data/nhis/earlyrelease/insur201609.pdf.

Cohn, J. (2020, March 6). The ACA, Repeal, And The Politics Of Backlash. Health Affairs Blog, https://www.healthaffairs.org/do/10.1377/hblog20200305.771008/full/.

Cohodes, S.R. et al. (2016). The Effect of Child Health Insurance on Schooling: Evidence from Public Insurance Expansions. The Journal of Human Resources, 51 (3), 727-759.

Collins, S. R., Gunja, M. Z., \& Aboulafia, G. N. (2020, August 19). U.S. Health Insurance Coverage in 2020: A Looming Crisis in Affordability. The Commonwealth Fund.https://www.commonwealthfund.org/publications/issue-briefs/2020/aug/looming-crisis-healthcoverage-2020-biennial.

Cooper, L. A., \& Williams, D. R. (2020, October 12). Excess Deaths From COVID-19, Community Bereavement, and Restorative Justice for Communities of Color. Journal of American Medical Association, 324 (15), 14911492.https://jamanetwork.com/journals/jama/fullarticle/2771762?widget=personalizedcontent\&previousarti cle=2764789. https://jamanetwork.com/journals/jama/fullarticle/2764789.

Cowan, C. A. et al. (2002). Burden of Health Care Costs: Businesses, Households, and Governments, 1987-2000. Health Care Financing Review, 23(3), 131-159. https://www.ncbi.nlm.nih.gov/pmc/articles/PMC4194768/.

Cox, C. et al. (2016). A New Way of Measuring Health Costs Sheds Light on Recent Health Spending Trends. http://www.healthsystemtracker.org/insight/a-new-way-of-measuring-health-costs-sheds-light-on-recenthealth-spending-trends/.

Davis, K. et al. (2014). Mirror, Mirror on the Wall - How the Performance of the U.S. Health Care System Compares Internationally. The Commonwealth Fund. http://www.commonwealthfund.org/ /media/files/publications/fundreport/2014/jun/1755 davis mirror mirror 2014.pdf.

Diener, R. (1983). Socialized Medicine Countries Ration Access, Foreign Market Specialist Says. ReviewFederation of American Hospitals, 16(6), 37-38.https://pubmed.ncbi.nlm.nih.gov/10263714/.

Dobson, A., DaVanzo, J., \& Haught, R. (2017). The Financial Impact of the American Health Care Act's Medicaid Provisions on Safety-Net Hospitals. The Commonwealth Fund.

Dorn, S., McGrath, M., \& Holahan, J. (2014, August). What Is the Result of States Not Expanding Medicaid? Results In-Brief, Urban Institute. https://www.urban.org/sites/default/files/publication/22816/413192-Whatis-the-Result-of-States-Not-Expanding-Medicaid-.PDF.

Duggan, M., Goda, G.S., \& Jackson, E. (2017). The Effects of the Affordable Health Care Act on Health Insurance Coverage and Labor Market Outcomes. Stanford University. Institute for Economic and Policy Research (SIEPR). https://siepr.stanford.edu/sites/default/files/publications/17-022.pdf.

Economic Report of the President. (2010). The Annual Report of the Council of Economic Advisers. https://www.gpo.gov/fdsys/pkg/ERP-2010/pdf/ERP-2010-other-8.pdf.

Evans, M. K. (2020, September 10). Health Equity - Are We Finally on the Edge of a New Frontier? New England Journal of Medicine, 338: 997-999.https://www.nejm.org/doi/full/10.1056/NEJMp2005944.

Faria, M. A. (2018). Free Market or Socialized Medicine for the future of US Health Care? Surgical Neurology International, 7(68).https://www.ncbi.nlm.nih.gov/pmc/articles/PMC4926555/.

Federal Register. (March 8, 2016). Patient Protection and Affordable Care Act. HHS Notice of Payment Parameters 2017. 81(45), 12203.

Fiedler, M., Aaron, H.J., Adler, L., \& Ginsburg, P.B. (June 22, 2017). Moving in the Wrong Direction-Health Care Under the AHCA. New England Journal of Medicine, 376 (25), 2407-2407. http://www.nejm.org/doi/pdf/10.1056/NEJMp1706848.

Friedman, Peter D., Andrews, Christina M., \& Humphreys, Keith. (March 9, 2017). How ACA Repeal Would Worsen the Opioid Epidemic. New England Journal of Medicine, pp. e16 (1) - e16 (2). http://www.nejm.org/doi/full/10.1056/NEJMp1700834.

Furman, J., \& Fielder, M. (October 20, 2016). More than 3 Million Children Have Coverage Due to Drop in Uninsured Rates Since 2008. The White House, Washington, DC. 
https://obamawhitehouse.archives.gov/blog/2016/10/19/more-3-million-children-have-coverage-due-dropuninsured-rate-2008.

Garfield, R., Majerol, M., Damico, A., \& Foutz, J. (November 2016). The Uninsured: A Primer. Kaiser Family Foundation.http://kff.org/uninsured/report/the-uninsured-a-primer-key-facts-about-health-insurance-andthe-uninsured-in-the-wake-of-national-health-reform/.

Gee, E., \& Spiro, T. (2019, April 18). Excess Administrative Costs Burden the U.S. Health Care System. Center for American Progress. https://www.americanprogress.org/issues/healthcare/reports/2019/04/08/468302/excess-administrativecosts-burden-u-s-health-care-system/.

Gee, E., \& Gurwitz, E. (2018, December 5). Provider Consolidation Drives Up Health Care Costs. Center for American Progress. https://www.americanprogress.org/issues/healthcare/reports/2018/12/05/461780/provider-consolidationdrives-health-care-costs/.

Goldstein, A., \& Eilperin, J. (October 13, 2017). Trump to End Key ACA Subsidies, a Move that Will Threaten the Law's Market Places. Washington Post. https://www.washingtonpost.com/national/health-science/trumpto-sign-executive-order-to-gut-aca-insurance-rules-and-undermine-marketplaces/2017/10/11/40abf774ae97-11e7-9e58-e6288544af98 story.html?utm term=.7f9dfd049911.

Goodnough, A. et al. (2020, March 23). Obamacare Turns 10: Here's a look at What Works and Doesn't. The New York Times. https://www.nytimes.com/2020/03/23/health/obamacare-aca-coverage-cost-history.html.

Gunja, M. Z., \& Collins, S. R. (2019, August 28). Who Are the Remaining Uninsured, and Why Do They Lack Coverage? The Commonwealth Fund. https://www.commonwealthfund.org/publications/issuebriefs/2019/aug/who-are-remaining-uninsured-and-why-do-they-lack-coverage.

Guth, M., Garfield, R., \& Rudowitz, R. (2020, March). The Effects of Medicaid Expansion under the ACA: Updated Findings from a Literature Review. Kaiser Family Foundation.http://files.kff.org/attachment/ReportThe-Effects-of-Medicaid-Expansion-under-the-ACA-Updated-Findings-from-a-Literature-Review.pdf.

Haberkorn, J. Graham, Cassidy Unveil last-ditch Obamacare Repeal Bill. Politico. http://www.politico.com/story/2017/09/13/obamacare-repeal-bill-senate-242665.

Hamel, L., Norton, M., Pollitz, K., Levitt, L., Claxton, G., \& Brodie, M. (January 2016). The Burden of Medical Debt: Results from the Kaiser Family Foundation/New York Times Medical Bills Survey. https://kaiserfamilyfoundation.files.wordpress.com/2016/01/8806-the-burden-of-medical-debt-results-fromthe-kaiser-family-foundation-new-york-times-medical-bills-survey.pdf.

Haven, S. (July 29, 2013). HHS: Obamacare Reduces Medicare Drug Costs. CBS News. https://www.cbsnews.com/news/hhs-obamacare-reduces-medicare-drug-costs/.

Himmelstein, D. U. et al. (2007). Medical Bankruptcy in the United States, 2007: Results of a National Study. http://petrieflom.law.harvard.edu/assets/publications/Warren_Medical_Bankrupcty in the United_States.pdf.

Holahan, J., Bowen, G., Headen, I., \& Lucas, A. (May 21, 2009). Health Reform: The Cost of Failure. Urban Institute.http://www.urban.org/sites/default/files/publication/30346/411887-Health-Reform-The-Cost-ofFailure.PDF.

Huelskoetter, T. (2017). Quarantining the Sick in High-Risk Pools Is Not a Replacement for the ACA. Center for American

Progress. https://www.americanprogress.org/issues/healthcare/reports/2017/02/16/415234/quarantining-the-sick-inhigh-risk-pools-is-not-a-replacement-for-the-aca/.

Kaiser Family Foundation. (October 2013). Summary of the Affordable Care Act. http://kff.org/health-reform/factsheet/summary-of-the-affordable-care-act/

Krugman, P. (2007, February 16). The Health Care Racket. The New York Times.https://www.nytimes.com/2007/02/16/opinion/16krugman.html.

$\mathrm{Ku}$, L. et al. (January 2017). Repealing Federal Health Reform: Economic and Employment Consequences for States. The Commonwealth Fund. http://www.commonwealthfund.org/publications/issuebriefs/2017/jan/repealing-federal-health-reform.

Kullgren, J. T. et al. (2012). Nonfinancial Barriers and Access to Care for U.S. Adults. Health Services Research, 47(1 Part 2), 462-485. https://www.ncbi.nlm.nih.gov/pmc/articles/PMC3393009/.

Kutilek, Paige. (May 27, 2016). The Truth About Medical Bankruptcy.https://www.youcaring.com/blog/2016/truth-medical-bankruptcy.

Litten, K. (2015, November 22). John Bel Edwards calls Medicaid expansion 'among the Highest Priorities.' The Times-Picayune. http://www.freerepublic.com/focus/f-news/3363877/posts.

Louisiana Department of Health. (2017). Medicaid Expansion Annual Report 2016/17. http://www.dhh.louisiana.gov/assets/HealthyLa/Resources/MdcdExpnAnnlRprt_2017_WEB.pdf.

MACPAC - Medicaid and CHIP Payment and Access Commission. Medicaid Enrollment Changes following the ACA. https://www.macpac.gov/subtopic/medicaid-enrollment-changes-following-the-aca/. 
Mandal, A (2014). Disparities in Access to Health Care. Medical Life Sciences. https://www.newsmedical.net/health/Disparities-in-Access-to-Health-Care.aspx.

Martin, A. B. et al. (2013). National Health Spending in 2012: Rate of Health Spending Growth Remained Low for the Fourth Consecutive Year. Health Affairs, 33 (1), 67-77.

McWilliams, J. M. (2009). Health Consequences of Uninsurance among Adults in the United States: Recent Evidence and Implications. The Milbank Quarterly, 87(2), 443494.https://www.ncbi.nlm.nih.gov/pmc/articles/PMC2881446/

Melhado, E. M. (2006). Health Planning in the United States and the Decline of Public-interest Policymaking. The Milbank Quarterly, 84(2), 359-440.https://www.ncbi.nlm.nih.gov/pmc/articles/PMC2690168/.

Miller, S. (December 22, 2017). What Individual Mandate Repeal Means for Employers. Society for Human Resource Management.https://www.shrm.org/ResourcesAndTools/hr-topics/benefits/Pages/individualmandate-repeal-affects-employers.aspx.

Moore, G. A. (1945). Socialized Medicine: Pro and Con. Journal of the National Medical Association, xxxvii (3), 86-89.https://www.ncbi.nlm.nih.gov/pmc/articles/PMC2616284/pdf/jnma00661-0015.pdf.

Organization for Economic Cooperation and Development. (2016). Health at a Glance 2015: How Does the United States Compare? https://www.oecd.org/unitedstates/Health-at-a-Glance-2015-Key-Findings-UNITEDSTATES.pdf.

Osborn, R. et al. (2016). In New Survey of 11 Countries, U.S. Adults Still Struggle with Access to and Affordability of Health Care. The Commonwealth Fund.https://www.commonwealthfund.org/publications/journalarticle/2016/nov/new-survey-11-countries-us-adults-still-struggle-access-and.

Richardson, J. A., Llorens, J. J., \& Heidelberg, R. L. (2019, August). Medicaid Expansion and the Louisiana Economy, 2018 and 2019. Louisiana State University. Public Administration Institute. https://lh.la.gov/assets/media/3and4.2019FinalReportMedicaidExpansionstudy.pdf

Richardson, J. A., Llorens, J. J., \& Heidelberg, R. L. (2018, March). Medicaid Expansion and the Louisiana Economy. Louisiana State University. Public Institute.https:/gov.louisiana.gov/assets/MedicaidExpansion/MedicaidExpansionStudy.pdf

Rosenbaum, S. (2011). The Patient Protection and Affordable Care Act: Implications for Public Health Policy and Practice. Public Health Reports, 126(1), 130-135.https:/www.ncbi.nlm.nih.gov/pmc/articles/PMC3001814/.

Rowan, K., McAlpine, D. D. \& Blewett, L. A. (2013, October). Access And Cost Barriers To Mental Health Care, By Insurance $\quad$ Status, $1999-2010 . \quad$ Health Affairs, https://www.healthaffairs.org/doi/full/10.1377/hlthaff.2013.0133.

Rushefsky, M. E. (2013). Public Policy in the United States (5 ${ }^{\text {th }}$ ed.). New York: M. E. Sharpe.

Shaffer, E. R. (2013). The Affordable Care Act: The Value of Systemic Disruption. American Journal of Public Health, 103(6), 969-972. https:/www.ncbi.nlm.nih.gov/pmc/articles/PMC3698736/.

Silvers, J. B. (2013). The Affordable Care Act: Objectives and Likely Results in an Imperfect World. Annals of Family Medicine, 11(5), 402-405. https://www.ncbi.nlm.nih.gov/pmc/articles/PMC3767707/.

Sohn, H. (2017). Racial and Ethnic Disparities in Health Insurance Coverage: Dynamics of Gaining and Losing Coverage over the Life-Course. Population Research Policy Review, 36(2), 181-201. https://www.ncbi.nlm.nih.gov/pmc/articles/PMC5370590/.

Sommers, B., Gunja, M., Finegold, K., \& Musco, T. (July 2015). Changes in Self-reported Insurance Coverage, Access to Care, and Health Under the Affordable Care Act. Journal of the American Medical Association, 314 (4), 366-374

Thompson, F. J. (2020, October 9). Six Ways Trump has Sabotaged the Affordable Care Act. Brookings Institution. https://www.brookings.edu/blog/fixgov/2020/10/09/six-ways-trump-has-sabotaged-the-affordable-care-act/.

Thompson, F. J., Gusmano, M. K., \& Shinohara, S. (2018). Trump and the Affordable Care Act: Congressional Repeal Efforts, Executive Federalism, and Program Durability. Publius: The Journal of Federalism, 48(3), 396-424.https://academic.oup.com/publius/article/48/3/396/4982766.

Tolbert, J., \& Orgera, K. (2020, November 6). Key Facts about the Uninsured Population. Kaiser Family Foundation. https://www.kff.org/uninsured/issue-brief/key-facts-about-the-uninsured-population/. https://aspe.hhs.gov/system/files/pdf/75441/report.pdf.

Virgets, S., Goidel, K., Barnes, S., \& Terrell, D. (2013). Louisiana Uninsured Population: A Report from the 2013 Louisiana Health Insurance Survey. http://dhh.louisiana.gov/assets/medicaid/LHIS/2013LHIS/LHIS2013Final.pdf.

Wherry, L. R., Miller, S.,Kaester, R., \& Meyer, B. D. (February 2015). Childhood Medicaid Coverage and Later Life Health Care Utilization. National Bureau of Economic Research (NBER), Working Paper No. 20929. http://www.nber.org/papers/w20929.

Wilensky, G. R. (2017). The First Hundred Days for Health Care. New England Journal of Medicine, 376 (25), 2407-2409. http://www.nejm.org/doi/pdf/10.1056/NEJMp1614965.

Willison, C. E., \& Singer, P. M. (2017, August). Repealing the Affordable Care Act Essential Health Benefits: 
Threats and Obstacles. American Journal of Public Health, 107(8), 1225-1226). https://www.ncbi.nlm.nih.gov/pmc/articles/PMC5508159/

Winters, D. (February 8, 2017). Kentucky, Arkansas Post Largest Drops in Uninsured Rates. Gallup-Healthways Well-Being Index. http://www.gallup.com/poll/203501/kentucky-arkansas-post-largest-drops-uninsuredrates.aspx. 